\title{
TRAJETÓRIA DO ORÇAMENTO PARTICIPATIVO DE PORTO ALEGRE: REPRESENTAÇÃO E ELITIZAÇÃO POLÍTICA*
}

\author{
Luciano Joel Fedozzi
}

Universidade Federal do Rio Grande do Sul (UFRGS), Porto Alegre, RS - Brasil.<fedozzi@cpovo.net>

\author{
André Luis Borges Martins \\ Universidade Federal do Rio Grande do Sul (UFRGS), Porto Alegre, RS - Brasil \\ <andre_sociais@yahoo.com.br>
}

http://dx.doi.org/10.1590/ 0102-6445181-223/95

As coisas mais delicadas, abandonadas à sua própria inércia, tendem a culminar numa brutalidade inimaginável.

T. W. ADORNO

A partir do contexto sociopolítico demarcado pelo período de redemocratização, o Brasil passou a vivenciar o surgimento e a expansão, em especial em âmbito local, mas também nas demais instâncias da Federação, de novos espaços de participação institucionalizada da sociedade civil, para discussão e decisão sobre políticas públicas, o que passou a ser denominado pela literatura de novas Instituições Participativas (IPs) (Avritzer, 2008; Pires e Vaz, 2010). De forma inédita, em termos de alargamento da democracia na história do país, são constituídas novas instituições calcadas na participação social para além dos processos de agregação de

\footnotetext{
* Trabalho apresentado no $35^{\circ}$ Congresso da Anpocs (Associação Nacional de Pós-Graduação em Ciências Sociais). É parte do projeto Inovações democráticas no Brasil: um balanço dos 24 anos de participação em Porto Alegre. Agradecemos o apoio do CNPq e os comentários dos participantes do GT Controles Democráticos e Instituições Políticas da Anpocs, reservando aos autores total responsabilidade pelo resultado ora apresentado.
} 
interesses, oportunizadas pelas eleições representativas do sistema partidário. Trata-se de um processo de inovação democrática, entendido como a

[...] criação institucional que vai além da promulgação de formas de participação cidadã direta, como o plebiscito, o referendo e a iniciativa popular, onde se articulam modalidades contínuas - não extraordinárias - de incidência social sobre o poder público e seu aparato administrativo, incluindo o próprio sistema político (Gurza Lavalle e Isunza Vera, 2010, p. 19) ${ }^{1}$.

Esse novo cenário de experiências inovadoras de gestão - contrário ao histórico autoritarismo brasileiro - vem concedendo ao país uma referência no que tange à ampliação da participação institucional na reforma da democracia. Dentre as IPs, além da proliferação dos Conselhos de Políticas 182 Públicas ou de Direitos, destaca-se o Orçamento Participativo (OP), inovação mais conhecida e difundida no mundo, inclusive em países de tradição democrática do Hemisfério Norte, a ponto de alguns autores europeus falarem alegoricamente no "retorno das caravelas" (Allegretti e Herzberg, 2004). De fato, após a emergência dos OPs no Brasil, com destaque para o paradigmático caso de Porto Alegre, vem ocorrendo um processo crescente de mundialização desse tipo de instituição participativa, com presença, hoje, em todos os continentes. Assim, o OP iniciou sua história no Velho Mundo ${ }^{2}$ e espalhou-se

\footnotetext{
1 Todas as traduções de citações aqui constantes foram feitas pelos autores, especialmente para uso neste artigo.

2 A Prefeitura de Paris adotou o OP em 2014 (ver em: <https://budgetparticipatif.paris.fr/bp/accueil.html $>$ ). Na cidade de Nova York, 22 representantes distritais do Conselho da Cidade (Câmara de Vereadores) desenvolvem o BP (ver em: <http://council.nyc.gov/PB >). Havana, desde 2014, desenvolve o Orçamento Participativo para a definição de prioridades de restauração urbana do espaço declarado Patrimônio Cultural da Humanidade no centro histórico da capital (ver em: <http://outraspalavras.net/outrasmidias/destaque-outras-midias/cuba-democracia-direta-na-restauracao-de-havana-velha/>).
} 
para os demais, em especial na Ásia e na África. Recentemente, está presente nas cidades de Paris, Nova York e Havana. Segundo o estudo de Sintomer et al. (2013), em 2013 havia cerca de 2,7 mil casos de OP no mundo. Evidentemente, são modelos distintos, decorrentes dos contextos locais e dos projetos políticos dos atores que o implementam (Sintomer et al., 2013; Dias, 2013). Apesar das diferenças em termos de desenho institucional, poder efetivo e inclusão de atores, cinco critérios são adotados para a definição mínima de uma prática de Orçamento Participativo: (1) a vertente orçamentária e/ou financeira é discutida de forma pública; o Orçamento Participativo lida com recursos escassos; (2) o envolvimento social no processo se dá no âmbito da cidade; o nível de bairro não é suficiente; (3) o processo tem momentos repetidos em instâncias, regras e critérios de participação e de escolha de prioridades orçamentárias; um encontro ou um referendo sobre questões financeiras não são exemplos de um Orçamento Participativo; (4) o processo inclui alguma forma de deliberação pública, no âmbito de encontros específicos ou fóruns; a abertura aos cidadãos das reuniões dos corpos administrativos ou políticos não é um Orçamento Participativo; (5) a prestação de contas sobre as decisões adotadas é essencial (Sintomer et al., 2013).

No Brasil, após a fase analítica que correspondeu às duas décadas de criação e expansão dessas novas IPs (incluindo-se estudos comparativos internacionais), a investigação acadêmica assume, hoje, caráter mais crítico sobre o funcionamento das mesmas, seus limites estruturais e contingenciais, efetividade e qualidade. Um dos temas atuais dessa agenda de investigação se refere à questão da representação no interior da participação, isto é, ao fenômeno da constituição de instâncias eletivas e processos de representação no modelo de grande parte das chamadas novas instituições participativas (Lüchmann, 2007; Gurza Lavalle, Houtzager, Castello, 2006a, Gurza Lavalle e Isunza, 2010; Almeida, 
2010). De fato, se, no formato dos Conselhos de Políticas Públicas ou de Direitos, o tema da representação e de sua possível elitização se coloca de forma mais evidente (Santos Jr., 2001; Tatagiba, 2005; Ribeiro, Fuks, Perissinotto, 2003; Alencar et al., 2013), nos OPs essa problematização teórica e empírica parece ter sido pouco explorada até o presente momento. O desenho dos OPs, que em geral permite participação mais ampliada e mais acessível aos setores pobres (Cortes e Gugliano, 2010; Ação Educativa e Ibope, 2003), somado ao enfoque normativo de parcela dos estudos sobre esse tipo de fórum participativo - que empolgou ativistas, gestores, pesquisadores e organizações do país e do exterior - talvez tenham contribuído para que o tema da representação não se constituísse como problema nos diversos casos de OPs estudados no país e no exterior.

O presente artigo toma os OPs, e mais especificamente o destacado caso de Porto Alegre (doravante OP), para 184 analisar uma das importantes questões que expressa o crescente processo de perda de qualidade dessa instituição participativa $^{3}$. O tema diz respeito à relação entre os participantes $e$ os seus representantes que são eleitos ${ }^{4}$ para as instâncias da estrutura de poder do OP. Pretende-se investigar a hipótese da elitização política no OP como fenômeno que contraria o ideário crítico aos "vícios da democracia representativa" presente na gênese e no desenvolvimento histórico dessa inovação democrática em Porto Alegre.

As seções a seguir do presente artigo abordarão: a definição de parâmetros teóricos sobre elitização, participação e representação; breve discussão sobre o tema da repre-

\footnotetext{
3 Cabe esclarecer que a perda de qualidade do OP de Porto Alegre se tornou notória a partir de 2000 (última gestão do PT) e vem piorando durante os anos de governo da nova coalizão partidária que assumiu a Prefeitura a partir de 2005. Sobre a necessidade de reformas no OP, ver a coletânea de artigos em Verle e Brunet (2002). 4 Investigações sobre aspectos relacionados ao público participante do OP de Porto Alegre foram objeto de estudos não focados no tema da representação. Ver, a respeito, Fedozzi (2008, 2009a, 2009b) e Fedozzi et al. (2013).
} 
sentação, diferenciando-a nos dois principais tipos de IPs, quais sejam, os Conselhos de Políticas Públicas ou de Direitos e os OPs; a síntese do funcionamento do OP de Porto Alegre, seguida da análise desse processo a partir de indicadores que configuram uma dupla face em sua atual etapa histórica: o caráter inclusivo do perfil social do público participante e o possível processo de elitização política em sua trajetória.

\section{Teorias democráticas: elitização, representação e participação}

Nas últimas duas décadas, o debate sobre a expansão e a consolidação da democracia como regime político mais factível e normativamente justificável tem sido acompanhado, paradoxalmente, pela acentuada crítica aos limites da representação eleitoral nos moldes das teorias democráticas hegemônicas desde o século passado, as teorias realistas, elitistas e pluralistas, cujos nomes de Weber, Schumpeter e Dahl são os mais destacados.

O Elitismo, ou Teoria das Elites, se constituiu inicialmente contra as ideias democráticas e socialistas presentes no limiar dos séculos XIX e XX. Formulada por Gaetano Mosca e Vilfredo Pareto, ela tinha como "lei sociológica inexorável" a retenção do poder por uma minoria (Grynszpan, 1996). Ao se desenvolver vinculado com o estudo das elites políticas, o Elitismo foi (re)definido

[...] segundo o qual, em cada sociedade, o poder político pertence sempre a um restrito círculo de pessoas: o poder de tomar e de impor decisões válidas para todos os membros do grupo, mesmo que tenha de recorrer à força, em última instância (Bobbio, 1983, p. 385).

Isso incluía o sufrágio universal que, segundo essa teoria, produziria legitimação às decisões da maioria pelos 
princípios de igualdade e de soberania popular adotados por esse sistema de representação. As posteriores interpretações dessa teoria fizeram-na de uma tese antidemocrática, uma tese realista dos sistemas políticos, incluindo-se o modelo democrático, que permite a concorrência aberta por meio do processo eleitoral (Mannheim, 1956; Dahl, 1971 [1954]). Para essa perspectiva, a existência de elites não é incompatível com a democracia. O Elitismo democrático passou, assim, a representar uma abordagem alternativa às teorias clássicas da democracia do século XIX ${ }^{5}$.

As teorias clássicas comungavam a ideia de que a forma democrática de governo estava identificada com uma medida substantiva do bem comum. A noção de soberania popular, defendida por Rousseau, e a noção da democracia como forma de autodeterminação moral, defendida pelas versões mais liberais, como em Stuart Mill, entendiam o processo de formação da vontade política como um processo racional de discussão e de 186 aferição do bem comum (Avritzer, 1996, pp. 99-151). Contrariamente a essa concepção, e em nome da defesa da democracia (no contexto de intenso conflito especialmente vivido pela Alemanha, após a Constituição de Weimar, entre correntes revolucionárias marxistas e nacionalistas de direita), as teorias elitistas da democracia sustentaram o caráter formal da democracia moderna. Nessa perspectiva, o estreitamento da participação é justificado como algo realista, baseando-se no entendimento de que a racionalidade do sistema encontra na seleção das elites a sua melhor viabilidade prática. A democracia é desvinculada de qualquer significado normativo (moral) devido à impossibilidade de interpretação racional do politeísmo de valores instaurado pela modernidade, conforme Weber (1994).

No pós-guerra, o surgimento da teoria pluralista da democracia (Dahl, 1971) também foi influenciado pelos teó-

5 O elemento comum à crítica elitista/realista é a tese da incompatibilidade, nas sociedades modernas, entre democracia, participação e racionalidade, suposta por Weber (1994 [1918]) e por Schumpeter (1961 [1942]). 
ricos do elitismo. Mas os pluralistas interpretam a democracia atribuindo centralidade ao papel dos múltiplos grupos de interesses em competição pelo poder. A ordem democrática exige a poliarquia, isto é, o equilíbrio entre os interesses em competição, no qual todos têm algum efeito sobre as políticas, sem que nenhum domine os mecanismos reais de governo (Dahl, 1971, 1989a, 1989b). Contrariamente às teorias elitistas, a participação é introduzida como um critério de avaliação da qualidade da poliarquia em cada país. Por isso, alguns analistas entendem que Dahl ocupa um lugar intermediário entre o elitismo/realismo e uma concepção participativa e normativa de democracia. Todavia, a teoria pluralista continua centrada na qualidade do processo eleitoral da democracia e, portanto, no polo da representação.

O surgimento das teorias da democracia participativa nos anos de 1970 e 1980, com Pateman (1992 [1970]), McPherson (1978) e Barber (2003 [1984]), e, da democracia deliberativa $^{6}$, na década de 1990 (Habermas, 1995, 1997, 1999; Cohen e Arato, 1992; Bohman, 1996; Bohman e Rehg, 1997; Benhabib, 1992; Dryzek, 1996, 2000; Fraser, 1992; Rawls, 1996; Gutmann e Thompson, 1996; Ackerman, 1991; Silva, 2004), irão estabelecer uma vertente crítica aos supostos elitistas/realistas ou mesmo pluralistas, ainda que com divergências internas nas duas correntes, participativa e deliberativa. De forma simplificada, o ponto em comum entre essas teorias é a tese de que a legitimidade da democracia está ancorada na reativação do princípio da soberania popular.

No caso das teorias da democracia participativa, a representação é entendida mais pelo viés negativo, inevi-

\footnotetext{
6 Além de correntes críticas aos limites da teoria deliberativa como modelo alternativo factível (Silva, 2006), parte da investigação sobre as novas IPs sob o enfoque deliberativo acabou reproduzindo uma sobreposição da teoria em relação à empiria. Essa perspectiva embasou estudos acríticos sobre os OPs (Avritzer e Pereira, 2005; Avritzer, 2002; Maíz, 2004; Fung e Wright, 2001), contribuindo para certa mitificação do caráter dessa inovação participativa. Um olhar crítico sobre o OP de Porto Alegre e sobre outros casos consta em Fedozzi (2000a, 2000b, 2002, 2008, 2009a), Navarro (2003), Silva (2006).
} 
tável, acentuando-se o polo da participação ${ }^{7}$. Já as teorias deliberativas, embora pressuponham o alargamento da participação e o fortalecimento das arenas públicas, estão assentadas na ideia comum de que a principal condição de legitimidade da democracia é a

[...] possibilidade da troca racional (intersubjetiva) de argumentos com possível transformação dos interesses e das preferências individuais nos fóruns deliberativos, por intermédio da reflexão sobre as decisões coletivas que lhe dizem respeito (Silva, 2004, pp. 1-3).

Os processos democráticos são legítimos quando eles permitem e encorajam a argumentação pública sobre questões específicas e também sobre as próprias regras do procedimento discursivo e o modo como elas são aplicadas (Cunningham, 2009, p. 194). Por isso, a noção de deli188 beração se relaciona à qualidade do processo que leva a uma decisão. O grau de formalização dos procedimentos é variado conforme as distintas correntes deliberativas (Silva, 2004, pp. 1-3). Desde então, cresceu a teorização e se diversificaram as posições sobre as possibilidades práticas da deliberação, seja entre os que acentuam o polo da participação (Fung e Wright, 2001; Elster, 1998; Santos e Avritzer, 2002; Coelho e Nobre, 2004; Pinto, 2004; Bobbio, 2010; Santos, 2002), seja na tentativa de conciliar os minipúblicos e as deliberações ampliadas (Chambers, 2003; Goodin, 2008), ou ainda na incorporação da deliberação ao polo da representação (Manin, 1997; Urbinati, 2006a, 2006b; Young (2006).

O debate teórico em torno da crítica democrática encaminha-se, na atualidade, para a superação da histórica duali-

\footnotetext{
7 Diferentemente dos modelos de Pateman e de McPherson, Barber (2003, p. 132) é exceção quando presume, em sua proposta de democracia forte, o banimento da representação das práticas democráticas.
} 
dade entre participação e representação. Inusitadamente, a crítica democrática vem se beneficiando não só da expansão de práticas participativas institucionais - de resto, assumida por atores muito diversificados, tais como o Banco Mundial, partidos de esquerda e movimentos sociais combativos - mas também dos consideráveis avanços teóricos em torno do tema da representação. O exímio trabalho de reconstrução histórica e esclarecimento conceitual realizado por Hanna Pitkin $(1967,2006)$ cumpriu papel importante nesse sentido, apesar de mais tarde a filósofa vir a propor a participação como corretivo da democracia (Pitkin e Shumer, 1982). Pitkin observa que os teóricos da representação esperam extrair de seus argumentos conotações positivas sobre a conduta dos representantes - o que esses deveriam fazer. Porém, para a autora, o conteúdo básico da representação é a necessidade paradoxal de tornar presente alguém (ou alguma coisa) que na verdade não está. Isso faz com que deixe de ter sentido "procurar uma conotação positiva para a representação” (Pitkin, 1979, p. 18). A postura adotada para analisar o fenômeno da representação, segundo a autora, depende da percepção que se tem dos problemas presentes na própria representação, tais como: (i) a natureza dos interesses ou das vontades que estão em jogo; (ii) as capacidades (políticas) de representantes e representados; (iii) o papel dos partidos políticos, do processo eleitoral e das organizações institucionais; e (iv) a própria natureza das questões políticas (Pitkin, 1979, p. 21). Nesse sentido, a representação é entendida como um sistema institucionalizado de responsabilidade política, realizado por designação para determinados "organismos políticos". A responsabilidade é percebida como um chamado para responder, prestar contas das próprias ações a quem tem o poder da designação. E, com isso, a possibilidade de indivíduos e ou grupos controlarem o poder em nome de quem não pode exercê-lo pessoalmente (Pitkin, 1979 , p. 21). Portanto, seguindo Pitkin, a noção de repre- 
sentação dá suporte a análises de como, por que e em que contexto indivíduos e/ou grupos estão representados em processos políticos institucionais.

A dissociação conceitual entre governo representativo e representação política - cuja fusão teórica durante boa parte do século XX inibiram o desenvolvimento da teoria política - permitiu superar os obstáculos epistemológicos que impediam interpretar o novo fenômeno de pluralização da representação (Pinto, 2004; Gurza Lavalle, Acharya, Houtzager, 2005; Lüchmann, 2007; Almeida, 2010). Esse novo fenômeno é caracterizado pelo governo representativo cuja representação eleitoral funciona com a simultânea diversificação dos atores, funções e instituições da representação política de caráter extraparlamentar, formal e informal (Gurza Lavalle, Houtzager e Castello, 2006a, p. 52).

As inovações participativas das últimas duas décadas, apesar da centralidade da representação dos atores da 190 sociedade civil nas mais diversas instâncias de decisão das políticas públicas, praticamente negligenciaram as transformações que a representação vem sofrendo. Certamente, são diversas as causas para tal déficit analítico. Dentre elas, provavelmente, pesou o enfoque analítico de correntes críticas à representação que atribuem normativamente vínculos entre participação e formas mais "diretas" de influência nas decisões políticas, em tensão (quando não em antagonismo) com a noção de representação, tomada como concepção "liberal da democracia”. Como disse Warren,

[...] embora experimentos de participação política nunca tenham sido tão promissores, a linguagem da participação exauriu muitas das suas capacidades críticas por sobreutilização e sobreampliação (apud Gurza Lavalle e Isunza Vera, 2011, p. 122). 


\section{Representação e tipos de Instituições Participativas}

Decorre dos avanços teóricos citados anteriormente o fato de que a agenda de pesquisa sobre as novas Instituições Participativas (IPs) precisa tornar transparente os

[...] mecanismos de representação no interior dos próprios espaços participativos (p\&r - participação e representação), cujas especificidades dizem respeito não apenas às diferenças com relação ao modelo $\mathrm{R}$ [representação], como também às diferentes modalidades de pËr" (Lüchmann, 2007, p. 150; grifos nossos).

Em decorrência, duas questões devem ser consideradas na démarche contemporânea sobre a superação da dualidade da representação e da participação. A primeira é que, no caso das novas IPs, a natureza da representação parlamentar não é a mesma. As novas IPs apresentam características específicas, por exemplo:

[...] participação e representação individual e coletiva; voluntária (e, portanto, radicalmente diferente da atuação política profissional e com todas as consequências dessa implicação); em diferentes espaços participativos; e com escolha de representantes mediante processos variados (fóruns, eleições, indicações etc.) (Lüchmann, 2007, p. 150).

A segunda questão se refere ao fato de que o fenômeno da pluralização da representação coloca novos desafios teóricos diante da legitimidade dessa nova institucionalidade, dadas as especificidades dos mecanismos de autorização e de accountability nos processos participativos. No caso dos Conselhos de Políticas Públicas ou de Direitos, a noção teórica da representação virtual juntamente com o conceito revisitado de accountability vêm sendo utilizados para dar conta 
do problema da autorização e da responsividade, isto é, às exigências de legitimidade nas experiências de representação extraparlamentar ${ }^{8}$. Os Conselhos de Políticas Públicas ou de Direitos apresentam um caráter mais complexo e difuso comparativamente aos OPs. Estão ancorados em critérios de legitimidade diferenciados, seja por afinidades e identidades associativas, por conhecimento ou expertise, ou pela trajetória política e social dos sujeitos escolhidos (Lüchmann, 2008, p. 89). Na maioria dos casos, são práticas de representação presuntiva, ou seja, unilaterais por parte daqueles que as exercem e não autorizadas pelos beneficiários (Gurza Lavalle, Houtzager e Castello, 2006a). Nos casos dos OPs, quando configuram combinações entre participação e representação, analisa-se, empiricamente, em cada caso, o tipo e a qualidade da representação. O caráter da representação no interior dos OPs, calcado na identidade territorial de moradores, apresenta melhores condições 192 para que o mandato dos representantes tenha sua legitimidade baseada na vontade expressa dos representados (mandato delegativo), principalmente quando há previsão de instrumentos de autorização e de prestação de contas. Ainda assim, podem se apresentar conexões distintas na relação p\&r: conteúdos explícitos e vinculantes do mandato dos representantes (mandato delegativo) ou liberdade de decisão (caráter fiduciário do mandato) (Bobbio, 1983).

O OP de Porto Alegre emergiu de um ideário de forte crítica à democracia representativa clássica ${ }^{9}$. Entretanto, seu funcionamento exige a complementaridade

\footnotetext{
8 Sobre pluralização da representação, ressignificação da accountability e a discussão sobre a legitimidade da participação na teoria democrática, ver Gurza Lavalle, Houtzager e Castello (2006a, 2006b); Gurza Lavalle e Isunza Vera (2011); Young (2006); Lüchmann (2007, 2008).

9 A criação do OP foi operada por um background influenciado pela concepção marxista-leninista-trotskista do duplo poder, representada pela experiência dos sovietes na Revolução Russa e vislumbrada nos Conselhos Populares em Porto Alegre. Ver, a respeito, Fedozzi (2000a).
} 
- inerentemente tensa - entre as formas clássicas da democracia representativa eleitoral (Executivo e Legislativo) e a participação de setores da sociedade civil, os quais também não prescindem de formas de representação por eleição dos conselheiros e delegados que irão compor as importantes instâncias representativas, respectivamente o Conselho do OP e os Fóruns de Delegados Regionais e Temáticos. A participação direta descreve um momento importante do funcionamento do OP de Porto Alegre. Nas assembleias abertas das Regiões e Temáticas são aprovadas, por voto individual, as prioridades orçamentárias, e são eleitos os conselheiros para formar o Conselho do Orçamento Participativo (COP). O número de indivíduos presentes nas assembleias estabelece quantos delegados serão escolhidos posteriormente para formar os Fóruns de Delegados. Durante o ciclo anual do OP, grande parte das decisões importantes ocorre nessas instâncias de representação. Não obstante, são amplamente utilizadas interpretações teóricas do OP que não correspondem a esse arranjo institucional. Conceitos como "democracia direta”, "esfera pública não estatal” (Utzig, 1996; Genro, 1995; Pont, 1997; Baierle, 2007), "estrutura autorregulada pelos próprios participantes” (Avritzer, 2003, p. 15) expressam versões ideológicas e mitificadoras do $\mathrm{OP}^{10}$. Esses conceitos supõem tanto a ausência (irreal) do Estado na configuração institucional do OP - superestimando a autonomia dos atores da sociedade civil e subestimando a importância da presença do Estado -, como negligenciam o importante papel que a representação possui no sistema de participação. Desde sua origem, o OP adotou o modelo delegativo de representação, com previsão do mandato imperativo e prestação de contas dos representantes para o público das Regiões e das Temáticas.

\footnotetext{
${ }^{10}$ A dinâmica empírica do OP se caracterizou como forma de cogestão, ou seja, construção compartilhada das regras para distribuição dos recursos e para o sistema de participação (Fedozzi, 1997, 2000a, 2000b; Abers, 2000; Gret e Sintomer, 2002).
} 
Eis a questão central da presente investigação: esse caráter fundador no modelo das relações p\&r historicamente instaurado pelo OP estaria sofrendo alterações substantivas? Em caso positivo, qual significado essas transformações adquirem em face do caráter crítico e inovador que marcou o OP de Porto Alegre como instituição da democracia participativa?

A seguir, analisaremos duas questões relevantes sobre o possível processo de elitização do OP: o perfil sociodemográfico dos participantes comparativamente à população de Porto Alegre; e a relação representantes/representados nas instâncias que configuram a estrutura de poder do OP. Antes, porém, cabe sintetizar o funcionamento do OP de Porto Alegre. É um processo de compartilhamento do poder de decisão sobre as prioridades orçamentárias de investimentos entre a administração municipal e a população da cidade, com as seguintes características 194 gerais: (a) existência de regras universais de participação em instâncias institucionais e regulares de funcionamento; (b) um método objetivo de definição da aplicação dos recursos para investimentos referentes a um ciclo de 24 meses entre as fases de orçamentação e de execução; e (c) um processo descentralizado em 17 Regiões e 6 Plenárias Temáticas.

\section{Participação, inclusão e representação OP como instituição inclusiva?}

A natureza territorial dos OPs e o caráter aberto à participação cidadã individual configuram, em geral, um desenho institucional que parece favorecer a inclusão de setores sociais historicamente excluídos dos processos clássicos de representação política ou mesmo de instâncias participativas institucionalizadas, a exemplo dos Conselhos de Políticas Públicas ou de Direitos. A síntese do perfil do público do OP de Porto Alegre indica que 
ele é formado paritariamente por homens e mulheres e por pessoas com idade proporcionalmente mais avançada do que a população da cidade. Os participantes do OP, comparativamente à população de Porto Alegre, tem menor renda familiar (até dois salários mínimos) (ver Gráfico 1) e menor nível de ensino (até o ensino fundamental) (ver Gráfico 2). É uma camada social cujas ocupações estão mais ligadas aos serviços sem qualificação, sejam manuais ou não. Em boa parte $(32,9 \%)$, eles possuem vínculos profissionais como empregados privados com carteira $(23,7 \%)$ ou sem carteira $(9,2 \%)$, autônomos $(19,6 \%)$, desempregados $(11,2 \%)$, aposentados/pensionistas $(9,7 \%)$ e "do lar" $(5,9 \%)$. Um elevado percentual não possui trabalho remunerado (mais de $30 \%$ ). Por outro lado, uma parcela considerável exerce jornada de trabalho acima de 40 horas semanais e até acima de 48 horas $(33,4 \%)$. Embora o público seja ligado às formas associativas, em especial às Associações de Moradores, percebe-se tendência de queda da taxa de associativismo do público em geral (Fedozzi et al., 2013).

\section{Gráfico 1}

Percentual de participantes do OP e habitantes de Porto Alegre com até 2 salários mínimos

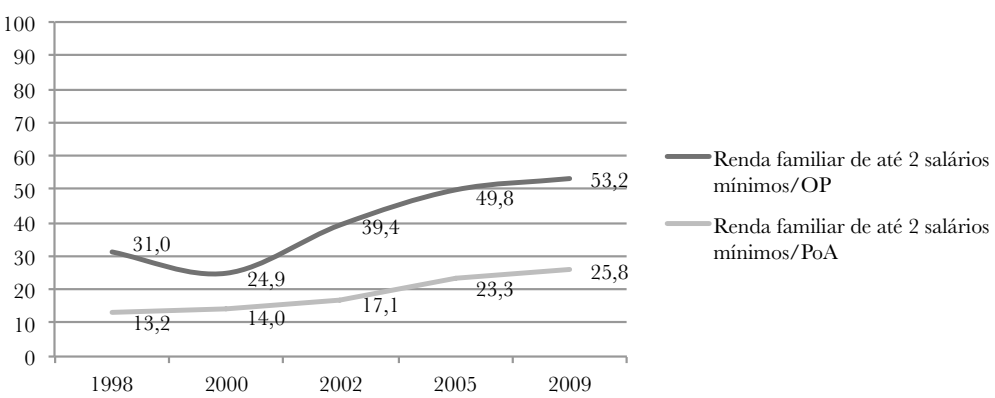

Fontes: Cidade (1999, 2002, 2003), Fedozzi (2007), Fedozzi et al. (2013), PED/ FEE (2009). 


\section{Gráfico 2}

Percentual de participantes do OP e habitantes de Porto Alegre com até ensino fundamental completo

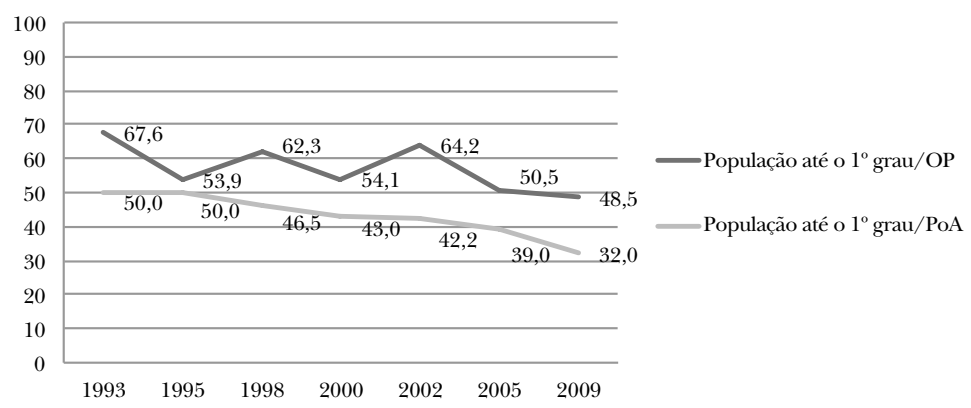

Fontes: Nuñez e Fedozzi (1993); Fase, PMPA, Cidade e Abers (1995); Cidade (1999, 2002, 2003); Fedozzi (2007); Fedozzi et al. (2013); IBGE (Censo demográfico 2010).

O público do OP constituiu-se historicamente com 196 relativa paridade entre mulheres e homens nas assembleias comunitárias. Entretanto, essa relativa igualdade da participação feminina, inclusive nas Associações de Moradores (AMs), não se refletia nas instâncias representativas do processo, o Conselho do OP (COP) e os Fóruns de Delegados Regionais e Temáticos. Nesses espaços de maior poder, os homens continuavam sendo maioria. A partir de 1998, contudo, as mulheres reverteram essa situação. Em 2005, tornaram-se maioria entre os participantes em geral $(52,8 \%)$, entre os que já foram conselheiros $(53,5 \%)$ e delegados $(52,4 \%)$, configurando representatividade semelhante à presença feminina na população da cidade (PED/FEE, 2009) ${ }^{11}$ (ver Gráfico 3).

${ }^{11}$ No OP de Porto Alegre, a paridade de gêneros na composição das chapas para eleição dos conselheiros (COP) e dos Fóruns de Delegados foi adotada como "recomendação" a partir de 2003. Há casos de OPs cuja paridade é regra obrigatória para a eleição dos representantes, a exemplo do que ocorre na cidade de Rosário, Argentina. 


\section{Gráfico 3}

Percentual feminino de participantes do OP e entre habitantes de Porto Alegre

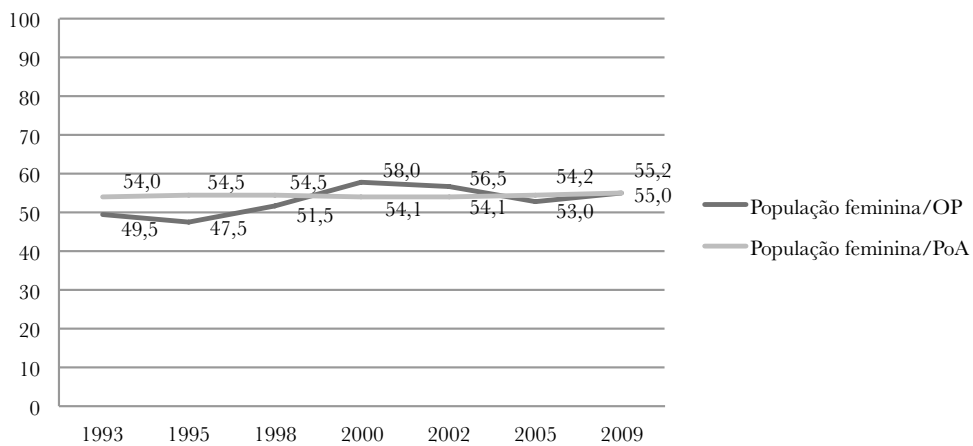

Fontes: Nuñez e Fedozzi (1993); Fase, PMPA, Cidade e Abers (1995); Cidade (1999, 2002, 2003); Fedozzi (2007); Fedozzi et al. (2013); PED/FEE (2009).

Quanto à participação das raças/etnias, o OP apresenta um quadro de crescente inclusão dos $\operatorname{pretos}^{12}$ em percentuais mais elevados do que a população preta da cidade. Em 2009, a diferença de autoidentificação chegou a ser mais de $100 \%$ a favor dos não brancos, relativamente ao que este grupo representa na população de Porto Alegre (ver Gráfico 4). Ao longo do tempo, acentuou-se a sub-representação dos brancos e a sobrerrepresentação dos pretos e indígenas, tanto nas assembleias, como nas instâncias representativas do OP (COP e Delegados), mesmo quando somados os percentuais dos negros e pardos (PED/FEE, 2009). Esse fenômeno pode significar tanto o maior envolvimento desses grupos étnicos no OP, como a tendência de maior autoidentificação em consequência do aumento da consciência étnico-racial verificada no país.

12 Apesar da autoidentificação como negro adotada pelo ativismo antirracista em Porto Alegre, optou-se por utilizar aqui a terminologia preto usada pela PED/FEE, a fim de propiciar análise comparativa do OP com a população da cidade. 


\section{Gráfico 4}

Percentual de participantes do OP e habitantes

de Porto Alegre de raça/cor/etnia não branca

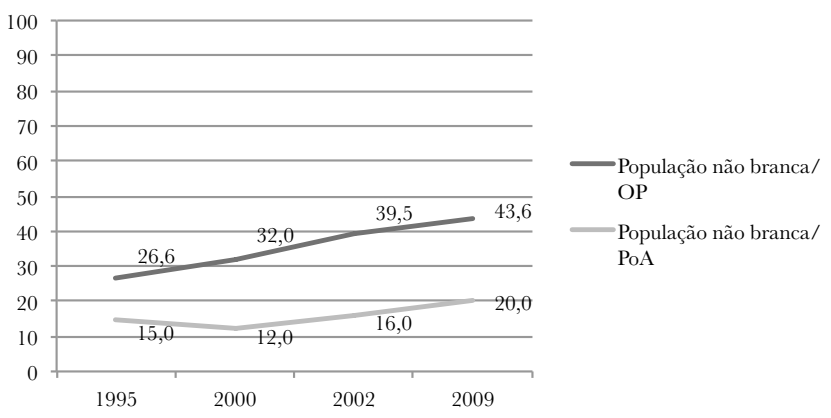

Fontes: Fase, PMPA, Cidade e Abers (1995); Cidade (2002, 2003); Fedozzi et al. (2013); IBGE (Censo demográfico 2010).

Os dados sobre o perfil sociodemográfico dos participantes do OP demonstram o elevado potencial dessa IP 198 para a inclusão de camadas sociais com menor capital econômico e cultural.

A seguir se analisará a dinâmica histórica da relação representantes/representados no interior do OP a partir de três indicadores: (1) a prestação de contas dos representantes (accountability); (2) o acesso às informações como condição para a participação mais equitativa e autônoma dos cidadãos, ou seja, o grau de conhecimento sobre a dinâmica do jogo da participação; e (3) e a renovação dos representantes, em especial para a instância de maior poder, o Conselho do Orçamento Participativo.

\section{OP e as relações representantes/representados: elitização política?}

A trajetória da accountability na representação do OP

Vasta bibliografia sobre teoria democrática e inovações participativas destaca o lugar central ocupado pela noção de accountability. De forma sintética, o termo é adotado 
para designar, no âmbito das práticas de controle social, a prestação de contas por meio de mecanismos estáveis e reconhecidos de autorização, responsabilização e de sanção na relação entre representantes e representados (O'Donnell, 1998; Gurza Lavalle e Isunza Vera, 2010, 2011; Wampler, 2005; Arato, 2002). Como já afirmado, no presente caso, interessa analisar possíveis mudanças na accountability horizontal ao longo da trajetória do OP (p\&r).

$\mathrm{Na}$ configuração institucional do OP de Porto Alegre, a autorização dos representantes (conselheiros e delegados) ocorre majoritariamente por eleições diretas dos participantes. Em especial, os conselheiros que formam o COP são eleitos pelos indivíduos com idade a partir de 16 anos presentes nas assembleias das Regiões e Temáticas. Os delegados podem ser eleitos ou indicados (pelas organizações sociais e/ou comunidades de determinada vila ou bairro) no momento posterior às Assembleias, conforme a proporção do número de indivíduos que delas tenham participado ${ }^{13}$. Como visto no ideário que animou a construção histórica do OP, a crítica ao modelo da democracia representativa liberal ensejou a adoção da representação delegativa (responsabilização pelos conteúdos e pleitos dos representados) e de sanção, com previsão do mandato imperativo (revogação do mandato pelos representados). Portanto, a prestação de contas dos representantes (supondo-se as dimensões da informação, da justificação das posições e da sujeição à sanção coletiva) adquiriu centralidade no modelo participativo.

A análise dos dados sobre o item "prestação de contas dos conselheiros e delegados", obtidos a partir da série histórica de pesquisas com os participantes do $\mathrm{OP}^{14}$, expressa a tendência de queda gradativa do grau de satisfação dos

\footnotetext{
${ }_{13}$ Proporção de um delegado para cada dez participantes das assembleias.

${ }^{14}$ São enquetes realizadas periodicamente com os participantes das assembleias do OP mediante a parceria entre UFRGS (Fedozzi), Prefeitura Municipal, ONG Cidade e eventuais pesquisadores do exterior. Ver mais em: <www.observapoa.com.br $>$.
} 
representados em relação à ação dos representantes. Isso indica nítida trajetória de diminuição da densidade da accountability. Como se pode verificar no Gráfico 5, ocorre variação significativa das respostas dadas à pergunta: "Na sua opinião, os conselheiros e delegados respeitam, encaminham e dão retorno à comunidade sobre suas reivindicações definidas a cada ano? Enquanto, em 1995, a resposta "sempre" foi de $62,4 \%$, em 2009 a mesma resposta obteve apenas 28,3\%. Contrariamente, nos mesmos anos a resposta "nunca" foi, respectivamente, de $1,4 \%$ e de $9,7 \%$. Em que pese a última pesquisa, em 2009, demonstrar a existência de uma avaliação ainda positiva sobre o papel e o vínculo dos representantes (a soma das respostas "sempre" e "na maioria das vezes" é maior do que a soma das respostas "poucas vezes" e "nunca"), percebe-se tendência de queda da qualidade da accountability na relação representantes/representados na trajetória do OP, conforme ilustra o Gráfico 5.

\section{Gráfico 5}

Opinião dos participantes do OP de Porto Alegre sobre o respeito, encaminhamento e retorno à comunidade das reivindicações definidas a cada ano dados, pelos conselheiros e delegados

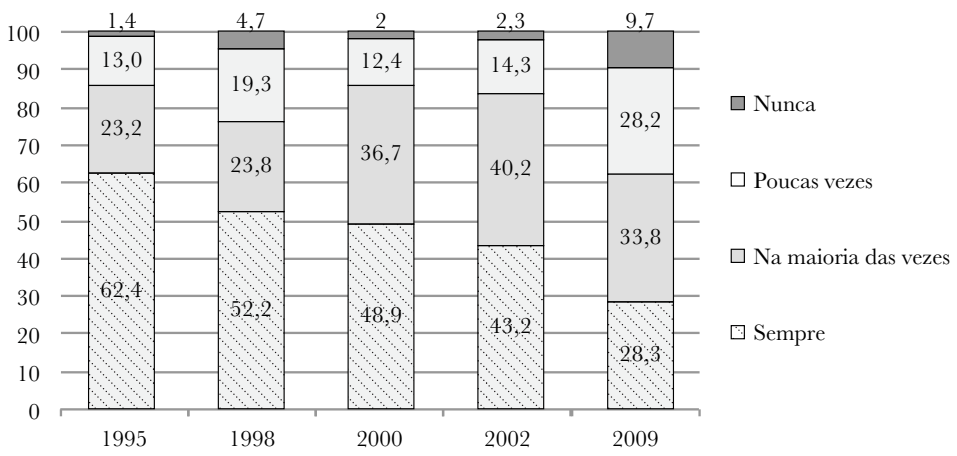

Fontes: Fase, PMPA, Cidade e Abers (1995); Cidade (1999, 2002, 2003); Fedozzi et al. (2013). 
Conhecimento e acesso às informações sobre as regras da participação

$\mathrm{O}$ conhecimento e a prática das regras que normatizam as interações nas instituições participativas constituem um ponto chave da autonomia cognitiva e moral dos cidadãos, necessária para uma situação mais igualitária da participação. A participação autônoma, conforme teorias democráticas clássicas e contemporâneas, a exemplo das teorias deliberativas, exige não somente o envolvimento de atores civis na própria criação das regras do jogo democrático (Rousseau, 1973; Arendt, 1987; Habermas, 1997; Lefort, 1987; Castoriadis, 1987), mas também um processo de socialização dessas regras, a fim de universalizar a participação nas decisões e oportunizar aprendizagens democráticas, independentemente da posição ocupada pelos indivíduos na instituição participativa.

Para fins do presente estudo, interessa conhecer a existência de possíveis desigualdades entre representantes e representados quanto ao conhecimento das regras do OP. A Tabela 1 é clara quanto a essa questão: a maioria dos participantes das assembleias (representados) $(64,6 \%)$ conhece "pouco as regras", inversamente ao estágio de conhecimento declarado pelos delegados e conselheiros (representantes).

Tabela 1

Tipo de participação por nível de conhecimento das regras do OP de Porto Alegre (2009)

\begin{tabular}{|c|c|c|c|}
\hline \multirow{2}{*}{$\begin{array}{c}\text { Nível de conhecimento } \\
\text { das regras (conhece) }\end{array}$} & \multicolumn{3}{|c|}{ Tipo de participação (em \%) } \\
\cline { 2 - 4 } & Assembleias & Delegados & Conselheiros \\
\hline Poucas & 64,6 & 12,5 & 4,5 \\
\hline Algumas & 25,6 & 33,0 & 22,7 \\
\hline A maioria & 8,5 & 38,4 & 39,4 \\
\hline Todas & 1,3 & 16,1 & 33,4 \\
\hline Total & 100,0 & 100,0 & 100,0 \\
\hline
\end{tabular}

Fonte: Fedozzi et al. (2013). 
Destaque-se a contrastante percepção dos conselheiros (72,8\% disseram conhecer "a maioria" ou "todas" as regras).

Em outra oportunidade, avaliou-se a questão do déficit cognitivo sobre informações básicas, como as regras de funcionamento do OP de Porto Alegre em decorrência da "pedagogia espontânea” que vigeu na maior parte de sua existência. O reconhecimento internacional adquirido pela inovação funcionou, paradoxalmente, como freio dogmático ante a necessidade de reavaliação constante dos limites apresentados pelo processo, configurando uma espécie de "síndrome dos pioneiros". Daí a relutância dos atores governamentais e da sociedade civil em adotar uma pedagogia da participação teoricamente embasada, visando à formação dos participantes, considerando-se a heterogeneidade em termos de escolarização e de socialização prévias à participação, bem como os distintos contextos sociourbanos em que estão inseridos (Fedozzi, 2007, 2008).

Os dados apresentados reafirmam os resultados gerais 202 de estudo anterior baseado em dados coletados uma década atrás (assembleias do OP de 1998). Naquela oportunidade, verificou-se tanto o uso instrumental e intransparente do conhecimento das regras do jogo, a fim de maximizar beneficios em prol dos grupos de pertencimento, como também se constataram práticas solidárias e dialógicas do conhecimento das regras, por outros delegados, a fim de universalizar benefícios para grupos com menor volume de capitais ou mesmo que não participavam do OP (Fedozzi, 2008) ${ }^{15}$. Mas se pode afirmar que, de forma geral, no item "acesso a informações e conhecimento das regras do OP”, a desigualdade entre representantes e representados favorece o processo de elitização política.

\footnotetext{
${ }^{15}$ Estudo realizado para investigar possíveis efeitos do OP sobre a consciência social dos seus participantes. O estudo apoiou-se na teoria do desenvolvimento sociomoral de Kohlberg (1969), cujas evidências empíricas são utilizadas por Habermas para sustentar a plausibilidade da consciência moral pós-convencional - denominada no referido estudo como consciência de "cidadania crítica". Constatou-se interveniência das variáveis escolaridade e tempo de participação no processo de aprendizagem de cultura cívica no OP.
} 


\section{A renovação dos representantes - conselheiros do OP}

$\mathrm{O}$ desenho institucional do OP de Porto Alegre adquiriu caráter dinâmico, isto é, passível de mudanças originadas no debate de seu Regimento Interno em cada ciclo anual, ainda que restrito, regra geral, às instâncias representativas (COP e Fóruns de Delegados). Além do caráter delegativo e revogável dos mandatos dos representantes, já discutido antes, uma das questões que expressou o ideário crítico da inovação participativa - contrária ao modelo elitista da democracia representativa - diz respeito à restrição do número dos mandatos pelo mesmo indivíduo, em especial dos conselheiros, e do caráter voluntário dos mesmos, isto é, inexistência de qualquer forma de ajuda financeira ou ressarcimento de custos (jetons). Não obstante, os dados indicam um processo de diminuição da taxa de renovação dos conselheiros, em especial a partir de 2001. Nesse ano, a renovação foi de $66,6 \%$, enquanto em 2008 foi de $34 \%$ (ver Gráfico 6). Em 2000, apenas 2,2\% dos conselheiros haviam sido eleitos cinco vezes ou mais. Em 2009, passou para $14,1 \%$ (ver Gráfico 7), e isso sem que tenha ocorrido diminuição da taxa geral de renovação dos participantes do OP (ver Gráfico 8). A progressiva diminuição da renovação dos conselheiros foi viabilizada por mudanças nas regras do Regimento Interno do OP. Em 2004 (último ano das administrações do PT), a alteração no Regimento possibilitou que os conselheiros retornassem ao Conselho (COP), mesmo depois de dois mandados, ainda que na condição de suplentes (Cidade, 2007). Entretanto, a possibilidade de permanência dos conselheiros no COP chegou ao ápice com a mudança em 2008, quando ocorreu a aprovação da reeleição permanente dos mandatos ${ }^{16}$.

\footnotetext{
${ }^{16}$ Ver Artigo $6^{\circ}$ - O mandato de Conselheiro(a) titular ou suplente é de 1 (um) ano de duração, havendo a possibilidade de reeleição. Fonte: PMPA. Regimento Interno do OP (2008/2009).
} 


\section{Gráfico 6}

Taxa de renovação do Conselho do Orçamento Participativo (1991-2008)

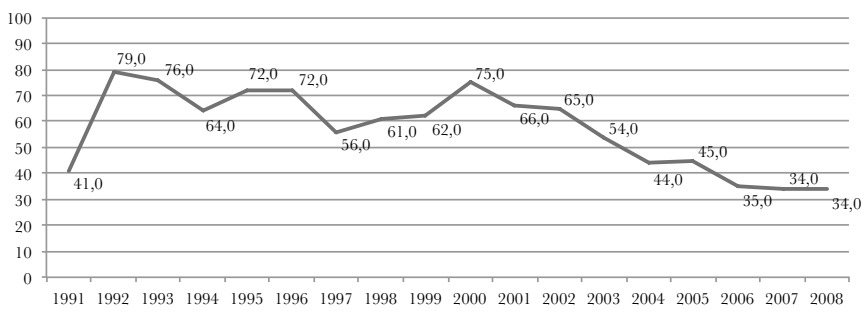

Fonte: Cidade (2007).

\section{Gráfico 7}

Vezes em que os participantes do OP foram eleitos conselheiros (em \%)

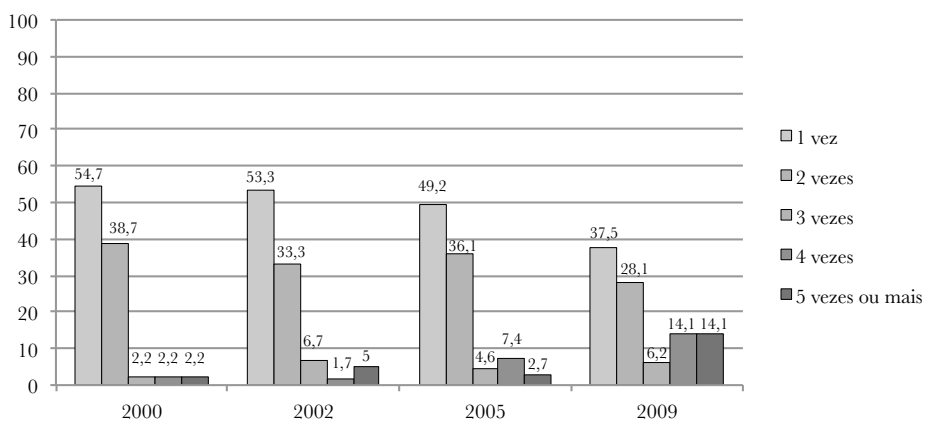

Fontes: Cidade (2002, 2003); Fedozzi (2007); Fedozzi et al. (2013).

\section{Gráfico 8}

Taxa de novos participantes e de comparecimentos em anos anteriores

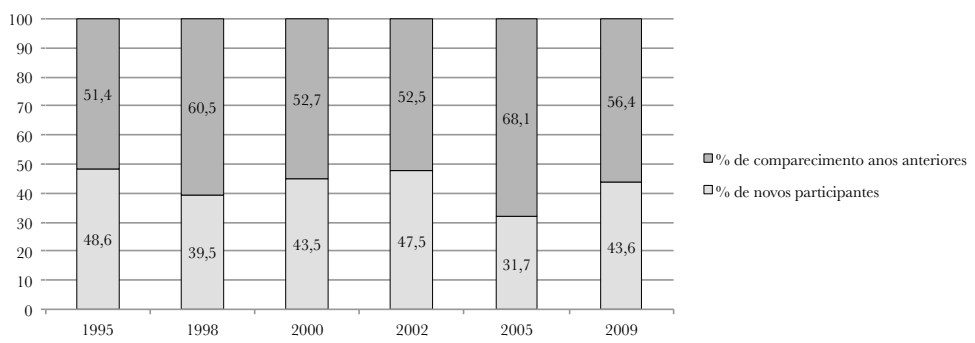

Fontes: Fase, PMPA, Cidade e Abers (1995); Cidade (2002, 2003); Fedozzi (2007); Fedozzi et al. (2013). 
Essa alteração nas regras do jogo é altamente simbólica diante do repertório dos atores participantes e do próprio Executivo, os quais historicamente procuravam distinguir o modelo de democracia participativa nascente das práticas consideradas tradicionais da democracia representativa, exemplificada pela crítica à Câmara de Vereadores. Nesse ideário crítico, propugnou-se pela necessidade de promover a renovação das lideranças e a igualdade de participação como forma de incentivo a aprendizagens democráticas e ao arejamento da democracia, daí a limitação dos mandatos a apenas uma reeleição, ainda que com a possibilidade de retorno após novo ciclo participativo na condição de titular ou de suplente.

Duas questões merecem análise sobre a mudança dessa regra. A primeira se refere ao fato de que foi aprovada pelos próprios conselheiros na instância de maior poder do OP (COP). Isto é, os representantes legislaram sobre o seu mandato sem autorização dos representados, o que contraria o princípio da soberania popular e do mandato delegativo presente na gênese e na construção do modelo de Porto Alegre. A segunda questão se refere à dissonância entre a nova regra da reeleição e a opinião dos representados. A opinião majoritária dos participantes das Assembleias é contrária à regra da reeleição permanente: $48 \%$ opinou pela restrição do número dos mandatos (somando-se as opções "apenas uma vez" ou "com prazo limitado") contra 37,9\% favoráveis à reeleição (Fedozzi et al., 2013) (Ver Gráfico 9). O fato representa um inédito distanciamento entre decisões dos representantes sobre o desenho institucional e a opinião dos representados, o que fortalece a hipótese da elitização política em curso na trajetória do OP de Porto Alegre.

Diante de tal fato relevante, cabe levantar algumas hipóteses, ainda que provisórias e sujeitas a aprofundamento, sobre as prováveis motivações e/ou condições que contribuíram para que os conselheiros adotassem essa alteração no desenho institucional do OP. É importante frisar que a provável eliti- 


\section{Gráfico 9}

Opinião dos participantes em relação à reeleição dos conselheiros no OP de Porto Alegre (2009)

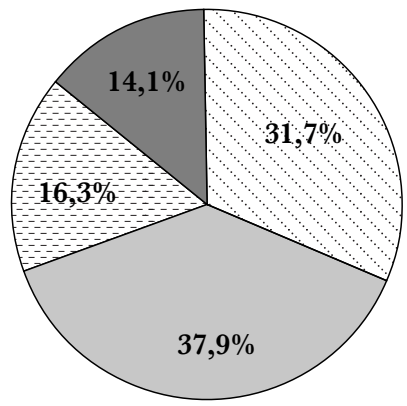

Favorável apenas uma vez

Favorável sem restrição

Favorável com prazo limitado

Não sabe/não respondeu

Fonte: Fedozzi et al. (2013).

zação política em curso não se encontra isolada do contexto de crise e reconfiguração do modelo de OP de Porto Alegre. Grosso modo, se pode aventar pelo menos quatro fatores inter206 ligados que compõem o contexto no qual ocorreu a mudança de uma regra importante na arquitetura da participação: (1) acentuação da captura de lideranças comunitárias pelo governo municipal; (2) mudanças no papel dos principais atores que constituíram o modelo histórico de cogestão do OP (Executivo e "comunidades"); (3) transformação do caráter das Associações de Moradores (principais organizações civis do OP) e diminuição do grau de associativismo; e, (4) por fim, práticas de lideranças da sociedade civil que expressam uma cultura política fortemente instrumental.

Veja-se sinteticamente: (a) a questão da captura ou tutela é tema chave na realidade das relações de poder que se processam nas IPs; Romão (2011) alerta para a relevância do sistema político-partidário nessas instituições. Os dados atuais do OP indicam pelo menos duas tendências presentes na formação do Conselho do Orçamento Participativo: diminuição do percentual de conselheiros sem filiação partidária, o que pode indicar aumento da influência da 
variável partidária na escolha dos conselheiros; mudanças na identidade partidária dos conselheiros favorável à nova coligação que assumiu em 2005. Quanto ao primeiro aspecto, apesar do aumento percentual da identificação partidária, é importante destacar que o grupo autodenominado de "comunitários" (críticos à política partidária) prossegue exercendo grande poder de influência na eleição de conselheiros e no conjunto do processo. Esse grupo se caracteriza por grande poder de articulação e de mobilização a partir de motivações pragmáticas, levada a efeito por lideranças de tipo tradicional e que agem com desenvoltura para se beneficiar dos outputs do processo. Quanto ao segundo aspecto, a Tabela 2 evidencia que, apesar da permanência de conselheiros identificados com o PT e de seu decréscimo no tempo, ocorreu crescimento de conselheiros filiados aos principais partidos da coligação que governa desde 2005 (PPS, PMDB, PTB e PDT). Em especial, cresceu a presença de conselheiros filiados ao PPS, PDT e PMDB, partidos que ocuparam o cargo de prefeito a partir de 2005, com o PDT assumindo em $2010^{17}$ e sendo reeleito em 2012 (tendo na vice-prefeitura, hoje, o PMDB). Quanto ao tema da reeleição, em que pese não haver atualmente clara divisão da opinião dos conselheiros identificados com partidos adversários (como será visto adiante), é importante lembrar que a primeira década do OP foi marcada por certos princípios compartilhados por lideranças mais afeitas à ideia da renovação política como atributo da democracia participativa. Não obstante, como visto antes, já em 2004 (último ano das gestões do PT) ocorre flexibilização quanto ao aumento do número dos mandatos.

\footnotetext{
${ }^{17}$ Após exercer o primeiro mandato (2005-2008) e ser reeleito, o Prefeito Fogaça renunciou ao cargo em 2010 para concorrer ao posto de governador do Estado do Rio Grande do Sul pelo PMDB, em 2010, perdendo para Tarso Genro (PT). O Vice-Prefeito José Fortunati, do PDT (antigo quadro do PT), assumiu o cargo de prefeito após a renúncia de Fogaça e também foi reeleito em 2012.
} 


\section{Tabela 2}

Filiação partidária entre os conselheiros titulares (2005, 2009, 2012)

\begin{tabular}{|c|c|c|c|c|c|c|}
\hline Filiação partidária & Casos & $\mathbf{2 0 0 5}(\%)$ & Casos & $\mathbf{2 0 0 9}(\%)$ & Casos & $\mathbf{2 0 1 2 ( \% )}$ \\
\hline Sem filiação & 23 & 53,5 & 20 & 45,0 & 17 & 37,0 \\
\hline PDT & 2 & 4,7 & 2 & 4,5 & 7 & 15,2 \\
\hline PT & 6 & 14,0 & 7 & 15,9 & 3 & 4,3 \\
\hline PTB & 3 & 7,0 & 4 & 9,1 & 2 & 8,7 \\
\hline PMDB & 1 & 2,3 & 1 & 2,3 & 4 & 8,7 \\
\hline PPS & 2 & 4,7 & 5 & 11,4 & 4 & 8,7 \\
\hline PSB & 2 & 4,7 & 1 & 2,3 & 4 & 8,7 \\
\hline PSDB & 1 & 2,3 & - & - & - & - \\
\hline PC do B & 3 & 7,0 & - & - & 1 & 2,2 \\
\hline PSOL & - & - & 1 & 2,3 & 2 & 4,3 \\
\hline PP & - & - & 2 & 4,5 & - & - \\
\hline PPL & - & - & - & - & 2 & 4,3 \\
\hline Total & 43 & 100,0 & 43 & 100,0 & 43 & 100,0 \\
\hline
\end{tabular}

Fontes: PMPA/OP/Plano de Investimentos, 2005, 2009, 2012; e TRE (2012).

Um segundo fator que ajuda a compreender a aprovação da regra de reeleição permanente dos conselheiros está relacionada à quebra do modelo baseado na cogestão do OP, isto é, ao compartilhamento do poder de decisão entre a administração municipal e o público participante sobre questões relevantes do seu desenho institucional. A noção de cogestão apoia-se nas críticas às teorias que supõem "virtudes cívicas intrínsecas à sociedade civil”, assim como certa divisão estanque entre Estado e sociedade civil (Gurza Lavalle, 1999, 2003; Dagnino, 2002; Silva, 2006; Abers e Bülow, 2011; Fedozzi, 1997). Como já afirmado, o processo instituinte do OP não ocorreu com a "autorregulamentação" dos atores da sociedade civil, e, sim, com o compartilhamento das decisões com papel ativo do Poder Executivo (Estado). As regras de participação e o método para 
a distribuição dos recursos contaram com o protagonismo dos atores governamentais, a fim de garantir pluralidade e evitar exclusão de segmentos comunitários que eram derrotados nas eleições dos representantes, bem como consignar caráter equitativo na alocação dos recursos orçamentários ${ }^{18}$. No episódio da mudança da regra dos mandatos, a prática da nova administração contrastou com esse modelo. $\mathrm{O}$ discurso de "autonomia do OP" parece ter sido útil à ausência de compromisso real com a sustentabilidade democrática do processo. Essa sustentabilidade requer papel ativo do Estado, incluindo-se a disputa, por meio de argumentos, sobre questões relativas às garantias democráticas e pluralistas na moldagem das Instituições Participativas. Esse compromisso significa, entre outros fatores, grande energia e dedicação de quadros qualificados e convictos do significado da participação popular na gestão pública, assim como trabalho unificado do conjunto da administração municipal para promover a gestão participativa. A grande quantidade de partidos na composição do novo governo (doze), em sua maioria historicamente não identificados com a participação na gestão pública, criou dificuldades para a manutenção do OP, objetivo que se colocou mais como realismo político diante do eleitorado (e do prestígio nacional e internacional do OP de Porto Alegre) do que convicção endógena do projeto vitorioso ${ }^{19}$. Soma-se a isso a decisão da administração municipal de introduzir um novo modelo de participação paralelo ao OP - a Governança Solidária Local

\footnotetext{
18 Todo o sistema de regramento da participação, incluindo-se o critério da proporcionalidade na eleição dos representantes ao COP, assim como o método criado para promover equidade na distribuição dos recursos, resultou da discussão, negociação e deliberação entre os representantes do governo municipal e os representantes da sociedade civil. Ver descrição detalhada em Fedozzi (2000a).

${ }^{19}$ Segundo pesquisa com os eleitores de Porto Alegre, o nível de concordância sobre atributos do OP foram os seguintes: muito importante $(65,88 \%)$; amplia a democracia $(57,26 \%)$; aumenta a eficiência do governo $(51,71 \%)$; a favor dos pobres $(53,6 \%)$; melhora a qualidade de vida $(56,91 \%)$. Ver BIRD $(2008$, p. 6$)$.
} 
(GSL) ${ }^{20}$. Esses fatores acabaram por secundarizar o lugar e o papel do OP na administração municipal. Além disso, tornou-se vantajoso para o novo governo ter presença significativa de apoiadores no Conselho do OP, no momento em que o processo carecia de legitimidade devido à crise financeira do município e a consequente inefetividade das decisões na última gestão do PT (2001-2004) ${ }^{21}$. O contexto favoreceu a alteração da regra que pretendia diferenciar o modelo participativo criado das práticas de burocratização e de oligarquização.

Entretanto, a mudança não ocorreria sem a agência dos representantes no COP. Adentra-se, assim, nos terceiro e quarto fatores antes elencados sobre as possíveis razões da aprovação da reeleição: as transformações que ocorreram nas formas de organização e de engajamento dos participantes e a mudança de opinião de lideranças sobre o caráter da representação, algo que remete ao questionamento sobre a 210 cultura política até então promovida pelo OP.

Quanto à primeira questão, é importante lembrar que - apesar do pluralismo associativo dos participantes - as Associações de Moradores tiveram historicamente papel destacado como principais atores coletivos do OP. O tempo de participação no OP somado à participação na direção de alguma Associação de Moradores explicam em 52\% a inserção no OP, medido pelas dimensões: presença, fala, representação e conhecimento das regras do jogo (Martins, 2011). Não obstante, a grande maioria dessas associações,

${ }^{20}$ A implantação da GSL contou com apoio da Unesco. O programa apoia-se em conceitos como orçamento social, parcerias com setores privados, território, balanço social, comitês gestores locais e transversalidade das políticas públicas (Busatto e Vargas, 2004). Algumas decisões adotadas nos quatro congressos da Cidade, realizados nas gestões do PT, são concernentes com esses elementos, em especial a previsão dos Comitês Gestores Locais nas regiões da cidade, a adoção de indicadores de avaliação e a qualificação das informações. Essas decisões dos congressos não foram efetivadas no período em que o PT governou a cidade.

${ }^{21}$ O passivo dos Planos de Investimentos do OP em dezembro de 2004 somava cerca de 950 demandas não realizadas ( $18 \%$ do total). Ver jornal De Olho na Cidade (2011). 
assim como ONGs e outras entidades, mudaram sua natureza reivindicativa e passaram a prestar serviços de assistência social em decorrência da nova política para essa área no país - o Sistema Único de Assistência Social (SUAS) -, e os consequentes convênios da Prefeitura com as organizações sociais $^{22}$, com evidentes efeitos de dependência financeira e, de resto, política. Ao mesmo tempo, percebe-se clara tendência de decréscimo da taxa de associativismo dos participantes: em 2009, pela primeira vez, a maioria dos participantes não possuía qualquer vínculo associativo ${ }^{23}$. As formas de recrutamento e de mobilização estão mais permeadas por relações de patronagem e de engajamento irrefletido de parte do público que vai às assembleias. Ao mesmo tempo, essa transformação do tecido associativo não deixou de se fazer presente no ativismo mais combativo ou mesmo entre os simpatizantes do PT e da Frente Popular. Ocorreu simultaneamente mudança ideológica de quadros que valorizavam a ampliação da participação política representada pelo OP e o abandono do processo por parte de uma militância mais crítica, incluindo-se correntes situadas à esquerda do partido que adotaram essa orientação ${ }^{24}$. Provavelmente, a "errática" gestão do PT à frente do governo

${ }^{22}$ Assistência Social é um dos três componentes do sistema de Seguridade Social no Brasil, entendida como direito do cidadão e dever do Estado. O Sistema Único de Assistência Social (SUAS) é o modelo de gestão que operacionaliza as ações de assistência social criado pelo Ministério do Desenvolvimento Social e Combate à Fome e pela Lei Orgânica de Assistência Social (LOAS) (Lei Federal $\mathrm{n}^{\circ}$ 8.742/1993). A estrutura do SUAS prevê a Política Nacional de Assistência Social, o Conselho Nacional de Assistência Social, que gere o Fundo Nacional de Assistência Social (FNAS), os conselhos estaduais e municipais, assim como as conferências. Em 2005, 98,8\% dos municípios brasileiros possuíam Conselho Municipal de Assistência Social. (IBGE, Perfil dos Municípios Brasileiros 2012 - Assistência social). Disponível em: <www.ibge.gov.br>. Acesso em: 12 out. 2012.

${ }^{23}$ A taxa de associativismo caiu de 61,8\%, em 1995, para 48,9\%, em 2009 (Fedozzi et al., 2013, p. 93).

${ }^{24}$ Em 2009, 33\% dos participantes do OP ainda se declararam simpatizantes do PT, partido com maior adesão entre o público do OP à época. Entretanto, essa simpatia não se expressa no processo eleitoral dos conselheiros (Fedozzi et al., 2013). 
do Estado do Rio Grande do Sul (1998-2002) ${ }^{25}$ e a crise do partido após a derrota em Porto Alegre contribuíram para aprofundar esse quadro. Assim, parcela importante de conselheiros identificados com o PT, por ação pragmática e por perda de referências críticas orientadoras do modelo de democracia participativa até então construído (contra o "encastelamento de lideranças tradicionais", "democracia direta" etc.), presente no discurso das lideranças de esquerda, também passou a se posicionar favorável à regra de reeleição dos conselheiros:

Sou favorável em qualquer nível. Para ser senador e vereador não tem limite. Por que para ser conselheiro do orçamento público deve haver? O Conselheiro vota o orçamento, mas no ano da execução não participa mais. Não acho que o OP deva ser bienal. Deve ser como no senado, com continuidade. Eleger parte dos representantes ano a ano, com mandatos maiores (Conselheiro Hamilton Gubert Viegas, Região Sul, participante há 18 anos, assessor de vereador do PT; PMPA, 2009, p. 4).

\footnotetext{
${ }^{25}$ A prática da gestão foi pautada pelo confronto permanente, assemelhada a um contexto de "tomada do poder". Exemplo emblemático foi a transposição mecânica do modelo do OP de Porto Alegre para o governo do Estado, sem envolvimento com instâncias institucionais de mediação, a exemplo das prefeituras e dos Coredes (Conselhos de Desenvolvimento Regional). Em Porto Alegre, o fenômeno do antipetismo surgiu principalmente após essa gestão no Estado (1998-2002) e se fortaleceu com o episódio do "mensalão". O peso das camadas médias é significativo na estrutura social da cidade. Em 2006, pela primeira vez na capital, o candidato Lula (PT) perdeu para Alckmin (PSDB), respectivamente, $42 \%$ e $53 \%$ ( $2^{\circ}$ turno) (Fonte: <http://www.eleicoes2012.info/candidatos-prefeito-porto-alegre-rs/>; acesso em: 23 ago. 2013). Da mesma forma, ocorreu em 2010, com Serra (PSDB) somando 55\% contra 44\% de Dilma (PT) (2 $2^{\circ}$ turno) (Fonte: <http://g1.globo.com/especiais/eleicoes-2010>; acesso em: 12 set. 2011). A outrora "cidade vermelha", reduto do PT, viu os índices do partido despencarem para 9,64\% nas eleições municipais em 2012, terceiro colocado atrás das candidaturas do PDT e do PC do B.
} 
As modificações no Regimento Interno do OP adotadas pelo Conselho ${ }^{26}$, sem envolvimento dos delegados, do público e de entidades das Regiões e das Temáticas, fortaleceram as instâncias de cúpula em detrimento do poder e do papel das instâncias de base. Essa curva na trajetória da dinâmica do OP é assim sintetizada na análise da ONG Cidade ${ }^{27}$ :

Modificações sutis, outras nem tanto, podem passar despercebidas, em especial aquelas que diminuem o poder dos Delegados e dos fóruns regionais e temáticos. Esses espaços perderam algumas atribuições fundamentais. Várias regras foram suprimidas. Foram eliminados alguns artigos do RI que davam poder aos Delegados de discutir e propor alterações na LDO e deliberar as alterações no regimento em conjunto com os Conselheiros. Há ainda nova norma que desobriga os Conselheiros de realizar pelo menos uma reunião mensal com Delegados e movimento popular organizado (grifos nossos).

[...]

O novo processo de apresentação de chapas de Conselheiros não facilita a inserção de novas lideranças e também não permite chapas constituidas a partir do contexto da assembleia. Como a(s) chapa(s) deverão ser apresentada(s) com 48 horas de antecedência, o processo de disputa de mais de uma chapa poderá gerar inchaços nas plenárias, ou esvaziamento, em caso de chapa única. Isso descaracteriza a assembleia do OP, na qual, além de escolher Conselheiros, deveriam também eleger as prioridades da Região e ser apresentada a prestação de contas do governo - o que tem se tornado cada vez mais raro. Outra questão que não ficou regrada é a forma como será divulgada a nominata da(s) chapa(s) concorrente(s) -

\footnotetext{
${ }^{26}$ Decisão adotada em janeiro de 2008.

${ }^{27}$ Centro de Assessoria e Estudos Urbanos criado em 1989. Desenvolve trabalho de acompanhamento, capacitação e acervo sobre o OP desde sua origem, além de outros instrumentos de participação e reforma urbana. Mais informações em: $<$ www.cidade.org.br $>$.
} 
essencial para garantir a lisura do pleito. Dessa forma, as alterações concentram as decisões no COP e aumentam, ainda mais, a distância entre este e os fóruns de Delegados (Jornal De Olho na Cidade, 2008; grifos nossos).

A diminuição da renovação dos representantes acentuou-se no período posterior às gestões da Frente Popular. Mas ela não pode ser interpretada como mero resultado da alternância de poder havida em 2004. A Tabela 3 mostra que, entre os participantes, não há diferença percentual significativa de opinião entre os simpatizantes dos partidos de esquerda (oposição e com ampla maioria identificada com o PT) e os simpatizantes dos partidos que apoiam a coligação que governa a cidade, sobre o tema da reeleição dos representantes.

\section{Tabela 3}

Opinião quanto à reeleição dos conselheiros por blocos partidários da situação e da oposição ao governo municipal de Porto Alegre (2009)

\begin{tabular}{|c|l|c|c|c|}
\cline { 3 - 5 } \multicolumn{2}{c|}{} & \multicolumn{3}{c|}{ Simpatia partidária } \\
\cline { 3 - 5 } \multicolumn{2}{c|}{} & Situação & Oposição & Total \\
\hline \multirow{3}{*}{ Opinião } & Favorável apenas uma vez & 38,0 & 31,0 & 31,7 \\
\cline { 2 - 5 } & Favorável com prazo limitado & 13,0 & 16,7 & 16,3 \\
\cline { 2 - 5 } & Favorável sem restrição & 35,0 & 38,3 & 37,9 \\
\cline { 2 - 5 } & Não sabe/não respondeu & 14,0 & 14,1 & 14,1 \\
\hline \multirow{2}{*}{ Total } & & 100,0 & 100,0 & 100,0 \\
\hline
\end{tabular}

Fonte: Fedozzi et al. (2013).

A elitização política em curso - emblematicamente representada pela tendência de perpetuação de conselheiros e pela concentração de poder na maior instância de representação - também expressa os limites da cultura política dos participantes do OP, conforme verificado em investigações anteriores. Para além da constatação de aprendizagens democráticas proporcionadas pelo processo 
participativo, são fortes os elementos que demonstram um significado instrumental da participação nas percepções e nas práticas dos participantes desse processo de longo curso (Fedozzi, 2008, 2009b).

A agenda atual sobre as investigações dos processos participativos destaca o tema da qualidade e da efetividade das novas IPs no país. Nesse contexto, uma das questões relevantes diz respeito ao exercício da representação dos atores da sociedade civil. $O$ estudo com esse enfoque ora apresentado sobre o OP de Porto Alegre, a mais longeva e destacada inovação participativa contemporânea, explorou a hipótese de uma possível tendência de elitização política em sua atual fase histórica. Como visto, partiu-se do pressuposto de que - apesar das transformações havidas no ideário político-ideológico que animou a gênese e a fase inicial de construção do OP - o caráter dessa inovação correspondeu a uma concepção crítica aos limites e vícios da democracia representativa liberal. Em que pese o caráter inclusivo do OP, como visto no perfil socioeconômico dos participantes vis-à-vis à população da cidade, os dados sobre os indicadores analisados fortalecem a hipótese de um processo de elitização política na relação representantes/representados. Para além das desigualdades do perfil socioeconômico dos representantes e dos representados, importam mais as mudanças nessa relação: diminuição da intensidade e da qualidade da accountability; diminuição da taxa de renovação dos representantes (conselheiros); alteração nas regras do jogo em benefício dos representantes (reeleição sem limites) adotada sem autorização dos representados e contrária à opinião majoritária dos mesmos; grande desigualdade de informações e conhecimento das regras da participação, propiciando uma situação heterô- 
noma dos representados. Enfim, a análise indica uma nova situação de distanciamento entre representantes e representados, fortalecendo a hipótese da elitização política em curso. Cabe a pergunta: estariam as novas IPs - mesmo as com perfil social inclusivo como é o caso dos OPs - condenadas a esse desiderato? O estudo não permite generalização a favor da tese da inexorabilidade da elitização ou oligarquização das instituições participativas. Novas pesquisas comparativas, suficientemente abrangentes em número de casos longevos, poderão oferecer elementos robustos a esse respeito, assim como sobre as possibilidades de os atores principais darem outro rumo às IPs desse tipo.

\section{Luciano Joel Fedozzi}

é professor do Departamento de Sociologia da Universidade Federal do Rio Grande do Sul (UFRGS).

\section{André Luis Borges Martins}

é doutorando em Ciência Política na UFRGS.

\section{BIBLIOGRAFIA}

ABERS, R. 2000. 'Do clientelismo à cooperação: governos locais, políticas participativas e organização da sociedade civil em Porto Alegre. Coleção Cadernos da Cidade, v. 5, n. 7, pp. 1-36.

ABERS, R.; BÜLOW, M. 2011. Movimentos sociais na teoria e na prática: como estudar o ativismo através da fronteira entre Estado e sociedade? Revista Sociologias, n ${ }^{\circ}$ 28, pp. 52-84.

AÇÃO EDUCATIVA; IBOPE. 2003. Pesquisa de opinião sobre participação $e$ controle social. Observatório da Educação e da Juventude. Disponível em: <http://www.acaoeducativa.org.br>. Acesso em: 27 maio 2005.

ACKERMAN, B. 1991. We the people. Foundations. Cambridge, MA: Harvard University Press.

ALENCAR et al. 2013. "Participação social e desigualdades nos conselhos nacionais”. Sociologias, Porto Alegre, ano 15, n. 32, pp. 112-46.

ALLEGRETTI, G.; HERZBERG, C. 2004. El retorno de las carabelas: los presupuestos participativos de América Latina en el contexto europeo. Amsterdam/Madrid: TNI Working Paper/FMI. 
ALMEIDA, D. 2010. "Metamorfose da representação política: lições práticas dos conselhos de saúde no Brasil”. In: AVRITZER, L. (org.). A dinâmica da participação local no Brasil. São Paulo: Cortez.

ARATO, A. 2002. "Representação, soberania popular e accountability". Lua Nova, n. 55/56, pp. 85-103.

ARENDT, H. 1987. A condição humana. Rio de Janeiro: Forense Universitária. AVRITZER, L. 1996. A moralidade da democracia: ensaios em teoria habermasiana e teoria democrática. São Paulo: Perspectiva; Belo Horizonte: Ed. UFMG. 2002. Democracy and the public space in Latin America. Princeton: Princeton University Press. 2003. "O Orçamento Participativo e a teoria democrática: um balanço crítico”. In: AVRITZER, L.; NAVARRO, Z. (orgs.). A inovação democrática no Brasil: o Orçamento Participativo. São Paulo: Cortez. 2008. "Instituições participativas e desenho institucional: algumas considerações sobre a variação da participação no Brasil democrático”. Opinião Pública, v. 14, n. 1.

AVRITZER, L.; PEREIRA, M. L. D. 2005. "Democracia, participação e instituições híbridas”. Revista Teoria e Sociedade, número especial, pp. 16-42.

BAIERLE, S. G. 2007. Lutas urbanas em Porto Alegre: entre a revolução política e o transformismo. Porto Alegre: Cidade (Centro de Assessoria e Estudos Urbanos).

BARBER, B. R. 2003 [1984]. Strong democracy: participatory politics for a new age. Berkeley: University of California Press.

BENHABIB, S. 1992. "Models of public space: Hannah Arendt, the liberal tradition, and Jürgen Habermas”. In: CALHOUN, C. Habermas and the public sphere. Cambridge, MA: MIT Press.

BIRD - Banco Internacional de Reconstrução e Desenvolvimento. 2008 (Relatório). Rumo a um Orçamento Participativo mais inclusivo e efetivo em Porto Alegre. Washington: BIRD/Banco Mundial.

BOBBIO, N. 1983. Qual socialismo? Rio de Janeiro: Paz e Terra. 2010. "Types of deliberation". Journal of Public Deliberation, v. 6, n. 2. Disponível em: <http://services.bepress.com/jpd/vol6/iss2/ art1>. Acesso em: 12 maio 2013.

BOHMAN, J. 1996. Public deliberation: pluralism, complexity, and democracy. Cambridge: MIT Press.

BOHMAN, J.; REHG, W. (eds.). 1997. Deliberative democracy: essays on reason and politics. Cambridge: MIT Press.

BUSATTO, C.; VARGAS, P. 2004. Governança Solidária Local. Fundamentos políticos da mudança em Porto Alegre. (Brochura). 
CASTORIADIS, C. 1987. Encruzilhadas do labirinto II. Rio de Janeiro: Paz e Terra. CHAMBERS, S. 2003. "Deliberative democratic theory". Annual Reviews Politic Science, Toronto, n. 6, pp. 307-26.

CIDADE - Centro de Assessoria e Estudos Urbanos. 1999, 2002, 2003.

Quem é o público do Orçamento Participativo: seu perfil, porque participa e o que pensa do processo. Porto Alegre: Cidade. 2007. Boletim, Porto Alegre, ano VI, n. 39, pp. 1-8.

COELHO, V. S. P.; NOBRE, M. (orgs.). 2004. Participação e deliberação.

Teoria democrática e experiências institucionais no Brasil contemporâneo. São Paulo: Ed. 34.

COHEN, J. 1989. "Deliberation and democratic legitimacy". In: HAMLIN. A; PETTIT, P. (eds.). The good polity: normative analysis of the State. Oxford: Basil Blackwell. 1999. Deliberation and democratic legitimacy. In: BOHMAN, J; REGH, W. Deliberative democracy: essays on reason and politics.

Massachusetts Institute of Technology.

COHEN, J.; ARATO, L. A. 1992. Civil society and political theory. Cambridge: MIT.

CORTES, S.; GUGLIANO, A. 2010. "Entre neocorporativos e deliberativos: uma interpretação sobre os paradigmas de análise dos fóruns participativos no Brasil". Sociologias, v. 2, n. 31, pp. 44-75.

CUNNINGHAM, F. 2009. Teorias da democracia. Porto Alegre: Artmed. DAGNINO, E. 2002. "Sociedade civil, espaços públicos e a construção democrática no Brasil: limites e possibilidades”. In: DAGNINO. E (org.). Sociedade civil e espaços públicos no Brasil. Rio de Janeiro: Paz e Terra. DAHL, R. 1971 [1954]. Polyarchy: participation and opposition. New Haven: Yale University Press. . 1989a. Democracy and its critics. New Heaven: Yale University Press. . 1989b. Prefácio à teoria democrática. Rio de Janeiro: Jorge Zahar.

DIAS, N. 2013. Esperança democrática: 25 anos de Orçamento Participativo. Lisboa: In Loco.

DRYZEK, J. S. 1996. Democracy in capitalist times: ideals, limits and struggles. Oxford: Oxford University Press. 2000. Deliberative democracy and beyond: liberals, critics, contestations. Cambridge: Cambridge University Press.

ELSTER, J. (ed.). 1998. Deliberative democracy. Cambridge: Cambridge University Press.

FASE; PMPA; CIDADE; ABERS. 1995. Pesquisa sobre a população que participa da discussão do orçamento público junto à Prefeitura Municipal de Porto Alegre. (Mimeo). 
FEDOZZI, L. 1997. Orçamento Participativo. Reflexões sobre a experiência de Porto Alegre. Porto Alegre: Tomo Editorial; Rio de Janeiro: FASEIPPUR, UFRJ. 2000a. O poder da aldeia. Gênese e história do Orçamento Participativo de Porto Alegre. Porto Alegre: Tomo Editorial. . 2000b. "Orçamento Participativo de Porto Alegre. Elementos para um debate conceitual”. In: FISCHER, N.; MOLL, J. (orgs.). Por uma nova esfera pública. Rio de Janeiro: Vozes.

2002. "A invenção permanente da democracia. Contribuições à discussão sobre o presente e o futuro do OP de Porto Alegre”. In: VERLE, J. BRUNET, L. Construindo um novo mundo. Porto Alegre: Guayí. 2007. Observapoa. Observando o Orçamento Participativo de Porto Alegre - análise histórica de dados: perfil social e associativo, avaliação e expectativas. Porto Alegre: Tomo Editorial.

2008. O Eu e os outros. Participação e transformação da consciência moral e cidadania. Porto Alegre: Tomo Editorial; Rio de Janeiro: Ippur/UFRJ; Observatório das Metrópoles.

. 2009a. "Democracia participativa, lutas por igualdade e iniquidades da participação”. In: FLEURY, S.; LOBATO, E. (orgs.). Participação, democracia e saúde. Rio de Janeiro: Centro Brasileiro de Estudos de Saúde. . 2009b. "Cultura política e Orçamento Participativo". Cadernos Metrópole, v. 11, n. 22, pp. 385-414.

FEDOZZI et al. 2013. Orçamento Participativo de Porto Alegre. Perfil, avaliação e percepções do público participante. Porto Alegre: Hartmann.

[Disponível em: <www.observapoa.com.br>].

FISHKIN, J. 2009. When the people speak: deliberative democracy and public consultation. Oxford: Oxford University Press.

FRASER, N. 1992. "Rethinking the public sphere: a contribution to the critique of the actually existing democracy. In: CALHOUN, C. Habermas and the public sphere. Cambridge, MA: MIT Press.

FUNG, A. 2004. Empowered participation: reinventing urban democracy. Princeton: Princeton University Press.

FUNG, A.; WRIGHT, E. O. 2001. "Deepening democracy: innovations in empowered participatory governance”. Politics and Society, n. 29, pp. 5-42.

GENRO, T. 1995. "O controle público não estatal e o orçamento participativo”. DEBATE: caderno do PT, Porto Alegre, n. 5, pp.11-13. GOODIN, R. E. 2003. Reflective democracy. Oxford: Oxford University Press. 2008. Innovating democracy: democratic theory and practice after the deliberative turn. Oxford: Oxford University. 
GRET, M.; SINTOMER, Y. 2002. L'Espoir d'une autre démocratie. Paris: La Découverte.

GRYNSZPAN, M. 1996. "A Teoria das Elites e sua genealogia consagrada”. BIB - Revista Brasileira de Informação Bibliográfica, n. 41, pp. 35-84.

GURZA LAVALLE, A. 1999. "Crítica ao modelo da nova sociedade civil”. Lua Nova, n. 47, pp. 121-35.

2003. "Sem pena nem glória. O debate sobre a sociedade civil nos anos 1990". Novos Estudos Cebrap, n. 66, pp. 91-109.

GURZA LAVALLE, A.; ACHARYA, A.; HOUTZAGER, P. 2005. "Beyond comparative anecdotalism: lesson on civil society and participation from São Paulo, Brazil”. World Development, v. 33, n. 6, pp. 40-48.

GURZA LAVALLE, A.; HOUTZAGER, P. P.; CASTELLO, G. $2006 a$.

"Democracia, pluralização da representação política e sociedade civil". Lua Nova, n. 67, pp 49-104.

. 2006b. "Representação política e organizações civis. Novas instâncias de mediação e os desafios da legitimidade”. RBCS, v. 21, n. 60, pp. 43-66.

GURZA LAVALLE, A.; ISUNZA VERA, E. 2010. "Precisiones conceptuales para el debate contemporáneo sobre la innovación democrática”. In: ISUNZA VERA, E.; GURZA LAVALLE, A. (orgs.). La innovación democrática en América Latina. Tramas y nudos de la representación, la participación y el control social. México: CIESAS/Universidad Veracruzana. 2011. "A trama da crítica democrática: da participação à representação e à accountability”. Lua Nova, n. 84, pp. 353-64.

GUTMANN, A.; THOMPSON, D. 1996. Democracy and disagreement: why moral conflict cannot be avoided in politics and what can be done about it. Cambridge, MA: Harvard University Press.

HABERMAS, J. 1995. "Três modelos normativos de democracia”. Lua Nova, n. 36, pp. 39-53. 1997. Direito e democracia: entre facticidade e validade. Rio de Janeiro: Tempo Brasileiro. $2 \mathrm{v}$. 1999. Teoria de la acción comunicativa. Madrid: Grupo Santillana de Ediciones.

HUNTINGTON, S. P. 1991. The third wave-democratization in the late twentieth century. Norman/London: University of Oklahoma Press.

IBGE - Instituto Brasileiro de Geografia e Estatística. 1970, 1980, 1991, 2000, 2010. Censos demográficos. Disponível em: <www.ibge.gov.br>. Acesso em: 12 out. 2012. . 2001. Indicadores dos municípios brasileiros. Disponível em: <www.ibge. gov.br>. Acesso em 12 out. 2012. 
2012. Perfil dos municípios brasileiros. Disponível em: <www.ibge.gov.

br>. Acesso em: 12. out. 2012.

IBGE, IPEA, ABONG e GIFE. 2004. Fundações privadas e associações sem fins lucrativos no Brasil-2002. Brasília: Ministério do Planejamento, Orçamento e Gestão; IBGE. (Estudos e Perspectivas - Informação Econômica, n. 4).

JACOBI, P. 1983. Movimentos populares urbanos e resposta do Estado: autonomia e controle versus cooptação e clientelismo. In: BOSCHI, R. (org.). Movimentos coletivos no Brasil urbano. Rio de Janeiro: Zahar. (Debates Urbanos, v. 5).

JORNAL De Olho na Cidade. Ano 12, n. 23, abr. 2008, p. 2. Ano 14, n. 31, maio 2011.

KOHLBERG, L. 1969. "Stage and sequence: the cognitive developmental approach to socialization”. In: GOSLIN, D. (ed.). Handbook of socialization theory and research. Illinois: Rand McNally.

LEFORT, C. 1987. Invenção democrática: os limites da dominação totalitária. São Paulo: Brasiliense.

LÜCHMANN, L. H. H. 2007. “A representação no interior das experiências de participação”. Lua Nova, n. 70, pp. 139-70. . 2008. "Participação e representação nos conselhos gestores e no

Orçamento Participativo". Cadernos CRH, Salvador, v. 21, n. 52, pp. 87-97. . 2009. A representação política nos conselhos gestores de políticas públicas.

Florianópolis: UFSC. (Relatório de pesquisa).

MAÍZ, R. 2004. "Modelos normativos de democracia". Revista Mexicana de Sociología, número especial, pp. 300-24.

MANIN, B. 1997. Los principios del gobierno representativo. Madrid: Alianza Editorial.

MANNHEIM, K. 1956. "The democratization of culture”. In: Essays on the sociology of culture. London: Routledge \& Kegan Paul.

MARTINS, A. L. B. 2011. Alcances e limites da inserção política no Orçamento Participativo de Porto Alegre. Trabalho de Conclusão de Curso.

Departamento de Sociologia. Porto Alegre: UFRGS.

McPHERSON, C. B. 1978. A democracia liberal: origens e evolução. Rio de Janeiro: Zahar.

NAVARRO, Z. 2003. "O Orçamento Participativo de Porto Alegre (19892002): um conciso comentário crítico”. In: AVRITZER, L.; NAVARRO, Z. A inovação democrática no Brasil. São Paulo: Cortez.

NUÑEZ, T.; FEDOZZI, L. 1993. Quem é quem no Orçamento Participativo. Interpretação de dados quantitativos da população que participa do OP em Porto Alegre. (Mimeo). 
O’DONNELL, G. 1998. “Accountability horizontal”. Agora, n. 8, pp. 5-34.

PATEMAN, C. 1992 [1970]. Participação e teoria democrática. Rio de Janeiro: Paz e Terra.

PED/FEE - Pesquisa de Emprego e Desemprego na Região Metropolitana de Porto Alegre/Fundação de Economia e Estatística. 2009. Porto Alegre: FGTAS/SINE-RS. (CD-Rom).

PINTO, C. R. J. 2004. "Espaços deliberativos e a questão da representação". RBCS - Revista Brasileira de Ciências Sociais, v. 19, n. 54, pp. 97-113.

PIRES, R. R. C.; VAZ, A. C. N. 2010. Participação faz diferença? Uma avaliação das características e efeitos da institucionalização da participação nos municípios brasileiros. In: AVRITZER, L. (org.). A dinâmica da participação local no Brasil. São Paulo: Cortez.

PITKIN, H. 1967. The concept of representation. Berkeley: University of California Press. . 1979. "O conceito de representação". In: CARDOSO, F. H.; MARTINS, C. E. (orgs.). Politica Ẽ Sociedade. São Paulo: Companhia Editora Nacional. . 2006. "Representação: palavras, instituições e ideias". Lua Nova, n. 67 , pp. 15-47.

222 PITKIN, H.; SHUMER, S. M. 1982. "On participation”. Democracy, v. 2, n. 4, pp. $48-53$.

PMPA - Prefeitura Municipal de Porto Alegre. 2005, 2009, 2012.

Orçamento Participativo. Plano de Investimentos. (Cadernos). . Regimento Interno do Orçamento Participativo 2008/2009. (Brochura). . 2009. Orçamento Participativo 20 anos. Publicação Especial, ago.

PONT, R. 1997. "A capital da democracia”. In: GENRO, T. (coord.). Porto da cidadania. Porto Alegre: Artes e Ofícios.

RAWLS. 1996. Political liberalism. New York: Columbia University Press. RIBEIRO, E. A.; FUKS, M.; PERISSINOTTO, R. M. 2003. "Cultura política e desigualdade: o caso dos conselhos municipais de Curitiba”. Sociologia e Política, Curitiba, n. 21, pp. 125-45.

ROMÃO, W. M. 2011. "Conselheiros do Orçamento Participativo nas franjas da sociedade política”. Lua Nova, v. 84, pp. 219-44.

ROUSSEAU, J-J. 1973 [1762]. Do contrato social. São Paulo: Victor Civita. (Coleção Os Pensadores).

SANTOS, B.; AVRITZER, L. 2002. "Para ampliar a cânone democrático". In: SANTOS, B. (org.). Democratizar a democracia: os caminhos da democracia participativa. V. 1. Rio de Janeiro: Civilização Brasileira: 
SANTOS, B. S. 2002. Democracia e participação: o caso do Orçamento Participativo de Porto Alegre. Porto: Edições Afrontamento. (Coleção Histórias e Ideias).

SANTOS Júnior, O. A. 2001. Democracia e governo local - dilemas da reforma municipal do Brasil. v. 1. Rio de Janeiro: Revan/Ippur/UFRJ-Fase.

SCHUMPETER, J. A. 1961 [1942] ). Capitalismo, socialismo e democracia. Rio de Janeiro: Fundo de Cultura.

SILVA, F. 2004. "Democracia deliberativa: avaliando seus limites". In: II CONGRESSO DA ASSOCIAÇÃO PORTUGUESA DE CIÊNCIA POLÍTICA. Fundação Calouste Gulbenkian. Lisboa, 19-20 janeiro.

SILVA, M. K. 2006. "Sociedade civil e construção democrática: do maniqueísmo essencialista à abordagem relacional”. Sociologias, n. 8, pp. 156-79.

SINTOMER, Y. et al. 2013. Participatory budgeting worldwide - Updated version. Bonn: Service Agency Communities, GIZ.

TATAGIBA, L. 2005. "Conselhos gestores de políticas públicas e democracia participativa: aprofundando o debate”. Revista Sociologia Política, n. 25, pp. 209-13.

TRE - Tribunal Regional Eleitoral do Rio Grande do Sul. 2012. Resultado das eleições. Disponível em: <http://www.tre-rs.gov.br/>. Acesso em: 15 out. 13. / Disponível em: <http://www.eleicoes2012.info/ candidatos-prefeito-porto-alegre-rs/>. Acesso em: 29 set. 2013.

URBINATI, N. 2006a. "O que torna a representação democrática?”. Lua Nova, n. 67, pp. 191-228.

. 2006b. Representative democracy: principles and genealogy. Chicago: University of Chicago Press.

UTZIG, J. E. 1996. "Notas sobre o governo do PT em Porto Alegre". Novos Estudos Cebrap, n. 45, pp. 209-22.

VERLE, J.; BRUNET, L. 2002. Construindo um novo mundo. Porto Alegre: Guayí.

WAMPLER, B. 2005. "Expandindo accountability através de instituições participativas: ativistas e reformistas nas municipalidades brasileiras". In: LUBAMBO, C.; COELHO, D. B.; MELO, M. A. (orgs.). Desenho institucional e participação política. Petrópolis: Vozes.

WEBER, M. 1994 [1918]. “O socialismo”. In: GERTZ, E. (org.). Max Weber Ẽ Karl Marx. São Paulo: Hucitec.

YOUNG, I. M. 2006. "Representação política, identidade e minorias". Lua Nova, n. 67, pp. 139-190. 


\section{TRAJETÓRIA DO ORÇAMENTO PARTICIPATIVO DE PORTO ALEGRE: REPRESENTAÇÃ̃ E ELITIZAÇÃO POLÍTICA}

LUCIANO JOEL FEDOZZI

ANDRÉ LUIS BORGES MARTINS

Resumo: $\mathrm{O}$ artigo trata da investigação sobre a qualidade das novas instituições participativas que surgiram nas últimas décadas no Brasil, focalizando o tema da representação no interior da participação. O Orçamento Participativo de Porto Alegre, caso emblemático de participação social e política, é adotado como elemento empírico da análise. Após discussão teórica sobre representação, participação e elitização, examinam-se duas situações aparentemente paradoxais: a permanência do caráter socialmente inclusivo do Orçamento Participativo em termos sociodemográficos; e as transformações recentes no caráter da representação, que sugerem um processo de elitização política em curso. São analisados dados a partir de três indicadores: (1) a accountability na relação representantes/representados; (2) conhecimento e informações sobre as regras da participação; e (3) mudanças nas normas sobre os mandatos dos representantes. A conclusão confirma a hipótese de elitização política na atual fase do Orçamento Participativo.

Palavras chave: Participação; Representação; Elitização; Orçamento Participativo.

\section{THE TRAJECTORY OF PORTO ALEGRE'S: PARTICIPATORY BUDGET: POLITICAL REPRESENTATION AND ELITIZATION}

Abstract: The article discusses reports research on the quality of the new participatory institutions that have emerged in recent decades in Brazil, focusing on the issue of representation within participation. Participatory Budgeting in Porto Alegre, an emblematic case of social participation, is adopted as an empirical element of analysis. 
After a theoretical discussion about representation, participation, and elitization, the article focuses on two seemingly paradoxical situations: the permanence of the Participatory Budget's socially inclusive character in socio-demographic terms; and recent changes in the character of the representation, which suggest a process of political elitization. Three indicators are selected to examine this hypothesis: (1) accountability in the relationship between representatives and those represented; (2) knowledge and information on the rules of participation; (3) changes in the rules of representatives' terms. The conclusion confirms the hypothesis of political elitism in the current phase of the Participative Budget.

Keywords: Participation; Representation; Elitization; Participatory Budgeting.

Recebido: 06/12/2013 Aprovado: 08/05/2015 